Article

\title{
Genetic Profiling and Comparison of Human and Animal Methicillin-Resistant Staphylococcus aureus (MRSA) Isolates from Serbia
}

\author{
Jelena Asanin ${ }^{1}{ }^{1}$, Dusan Misic ${ }^{2}$, Ksenija Aksentijevic ${ }^{2}$, Zoran Tambur ${ }^{3}$, Bojan Rakonjac ${ }^{4}$, \\ Ivana Kovacevic ${ }^{5}$, Joachim Spergser ${ }^{6}$ and Igor Loncaric ${ }^{6, * \mathbb{D}}$ \\ 1 Innovation Center of Faculty of Technology and Metallurgy, University of Belgrade, 11000 Beograd, Serbia; \\ jelenaasanin@gmail.com \\ 2 Faculty of Veterinary Medicine, University of Belgrade, 11000 Beograd, Serbia; dusan@vet.bg.ac.rs (D.M.); \\ pojavica@gmail.com (K.A.) \\ 3 Institute of Hygiene Military Medical Academy, Belgrade, Serbia and Faculty of Stomatology in Pancevo, \\ 11000 Beograd, Serbia; tambur.zoran@gmail.com \\ 4 Institute of Microbiology Military Medical Academy, 11000 Beograd, Serbia; bonatejo@gmail.com \\ 5 Institute of Hygiene Military Medical Academy, 11000 Beograd, Serbia; ivanchichica@gmail.com \\ 6 Institute of Microbiology, University of Veterinary Medicine, 1210 Wien, Austria; \\ joachim.spergser@vetmeduni.ac.at \\ * Correspondence: Igor.Loncaric@vetmeduni.ac.at; Tel.: +43-(1)-250772115
}

Received: 10 February 2019; Accepted: 13 March 2019; Published: 16 March 2019

\begin{abstract}
The aim of this study was to characterize a collection of methicillin-resistant Staphylococcus aureus (MRSA) isolates of human and animal origin from Serbia. In total, 36 MRSA isolates-30 obtained from humans and six from companion animals-were investigated by PCR for the presence of antibiotic and biocide resistance determinants and virulence genes (PVL-Panton-Valentine leukocidin, ETs - exfoliative toxins, TSST—-toxic shock syndrome toxin, SEs—staphylococcal enterotoxins, and MSCRAMMs - microbial surface components recognizing adhesive matrix molecules and biofilm). Isolates were analyzed by staphylococcal cassette chromosome mec (SCCmec), spa, and dru typing, as well as by multiple locus variable number of tandem repeat analyses (MLVA), multilocus sequence typing (MLST), and subsequently, eBURST. The majority of human MRSA isolates were resistant to gentamicin, erythromycin, clindamycin, and ciprofloxacin. Different antibiotic resistance genes were detected: aac-aphD, ant $\left(6^{\prime}\right)-\operatorname{Ia}, \operatorname{erm}(\mathrm{A}), \operatorname{erm}(\mathrm{B}), \operatorname{erm}(\mathrm{C}), \operatorname{tet}(\mathrm{K}), \operatorname{tet}(\mathrm{M}), \operatorname{fex} A$, and $\operatorname{cat}{ }_{\mathrm{pC} 221}$. All isolates were susceptible to teicoplanin and linezolid. SCCmec type III was prevalent in human isolates, while SCCmec elements in animals were mostly nontypeable. $\mathrm{t} 037$ was the predominant spa type in human and $\mathrm{t} 242$ in animal MRSA isolates. The prevalent $d r u$ type was dt11c in human and dt10a in animal MRSA isolates. MRSA isolates exhibited 27 different MLVA types. ST239 was predominant in human, while ST5 was prevalent in canine MRSA isolates. PVL was found in two, while tsst-1 was detected in three human isolates. Human-associated clones belonging to ST5, ST45, and ST239 MRSA clones were discovered in companion animals, which suggests anthropozoonotic transmission.
\end{abstract}

Keywords: MRSA; humans; animals; antibiotic resistance; SCCmec typing; dru typing; spa typing; MLVA; MLST

\section{Introduction}

Methicillin-resistant Staphylococcus aureus (MRSA) is a well-known and widespread pathogen that has the ability to cause a wide spectrum of clinical diseases in humans and various animal species [1]. MRSA strains carry a diverse and transmissible genetic element designated as staphylococcal cassette 
chromosome mec (SCCmec) [2]. To date, thirteen major types of SCCmec have been identified, as well as a number of deletion variants, composite, and irregular elements [3,4]. In MRSA isolates of human and animal origin, mecA and mecC genes have been detected [5]. MRSA strains are notorious for being multidrug-resistant [6]. In addition to mec genes, MRSA strains possess many different antibiotic, heavy metal, and disinfectant resistance genes, as well as virulence determinants that could be located on SCCmec and SCC elements, but also on the other mobile genetic elements (MGEs) [7].

MRSA is one of the leading causes of hospital-acquired infections. Healthcare-associated MRSA (HA-MRSA) infections represent a significant burden due to increased morbidity that leads to extended hospital stays and extra hospitalization costs but also cause higher mortality than methicillin-susceptible S. aureus (MSSA) [6]. At first, HA-MRSA clones were limited to hospitals and later, multidrug-resistant HA-MRSA strains moved from hospital settings to the community [6]. By contrast, community-associated S. aureus (CA-MRSA) emerged in the community, among healthy young individuals with no prior connections to the healthcare system. CA-MRSA strains often carry genes encoding Panton-Valentin leukocidin (PVL), which is responsible for severe infections of skin and soft tissue and necrotizing pneumonia [8]. CA-MRSA strains have become a serious public health problem, as these virulent strains rapidly spread in the general population and close social groups, causing outbreaks [8].

At present, CA-MRSA strains have shifted from the community to hospitals, where these once generally susceptible strains have acquired additional antibiotic resistance determinants [9,10].

S. aureus is capable of colonizing skin and mucous membranes of healthy dogs and cats, but the frequency of S. aureus isolation is low: generally lower than $10 \%$ [11]. Prevalence data on MRSA presence in healthy dogs and cats are variable, but most studies have reported rates of 0-6\% [11].

The information on MRSA from Serbia is scarce, mainly reported on the presence and characterization of MRSA isolates from humans and food animals [12-18], but to date, no study on MRSA presence in companion animals has been published.

The high proximity of companion animals to humans brings benefits for both. On the other hand, this proximity could also be associated with transmission in both directions, zoo-antrophogenic and vice versa, of antibiotic-resistant bacteria such as MRSA. Thus, due to the threat posed on animal and human health by the emergence of MRSA in humans in Serbia as well as the total scarcity of published data on MRSA from companion animals, the aim of the present study was to characterize and compare MRSA isolates originating from unrelated humans and companion animals during a certain point of time in order to determine any similarity and differences between human and animal MRSA isolates from Serbia.

\section{Results}

\subsection{Antibiotic Susceptibility Testing}

All tested MRSA isolates originating from humans $(n=30)$ were susceptible to teicoplanin and linezolid, while 25 isolates were resistant to gentamicin and one to amikacin, and the presence of corresponding gene aac-aphD was revealed in 26 isolates, while the ant $\left(6^{\prime}\right)$-Ia gene was found in 25 isolates; 22 isolates were resistant to erythromycin and clindamycin (two isolates showed inducible clindamycin resistance), which was reflected in that carrying $\operatorname{erm}(\mathrm{A})(7), \operatorname{erm}(\mathrm{B})(7)$, and $\operatorname{erm}(\mathrm{C})(17)$ genes. Six isolates were resistant to tetracycline and the following corresponding genes were detected: tet $(\mathrm{K})$ in 4 and tet $(\mathrm{M})$ in 21 isolates; four isolates were resistant to chloramphenicol and matching genes fex $A$ and cat $t_{\mathrm{pC} 221}$ were found in two and four isolates, respectively (Table 1). Resistance to ciprofloxacin was detected in 23 isolates, to rifampin in two, and to trimethoprim-sulfamethoxazole in one isolate. All MRSA isolates from animals $(n=6)$ were susceptible to amikacin, trimethoprim-sulfamethoxazole, chloramphenicol, teicoplanin, and linezolid. Resistance to gentamicin was recorded in three isolates, and the corresponding aac-aphD gene was detected in four isolates. Resistance to erythromycin and clindamycin (inducible type) was found in one isolate, and the presence of the matching $\operatorname{erm}(\mathrm{C})$ was revealed in that isolate. Resistance to tetracycline was exhibited by one isolate and in that isolate, corresponding tet $(\mathrm{K})$ and tet $(\mathrm{M})$ genes were detected. Resistance to ciprofloxacin in was found in two isolates and resistance to rifampin in one isolate, while the presence of ant $\left(6^{\prime}\right)$-I $a$ was in revealed in three isolates (Table 1). 
Table 1. Molecular characterization, antimicrobial resistance, and toxin profile of the methicillin-resistant Staphylococcus aureus isolates investigated.

\begin{tabular}{|c|c|c|c|c|c|c|c|c|c|c|c|c|c|}
\hline \multirow[b]{2}{*}{ ID } & \multirow[b]{2}{*}{ Host } & \multirow[b]{2}{*}{ Clinical Site } & \multirow[b]{2}{*}{ spa } & \multirow[b]{2}{*}{$d r u$} & \multirow[b]{2}{*}{ SCCmec } & \multirow[b]{2}{*}{ MLVA* } & \multirow[b]{2}{*}{ ST } & \multirow[b]{2}{*}{$\mathrm{CC}$} & \multicolumn{2}{|c|}{ Antimicrobial Resistance } & \multirow{2}{*}{$\begin{array}{l}\text { Virulence } \\
\text { Factors }\end{array}$} & \multirow[b]{2}{*}{ IEC *** } & \multirow[b]{2}{*}{ Miscellaneous Genes ***** } \\
\hline & & & & & & & & & Phenotype ${ }^{* *}$ & Genes Detected & & & \\
\hline S264 & Cat & Skin swab & $\mathrm{t} 127$ & $\mathrm{dt} 7 \mathrm{o}$ & NT & 15 & ST1 & $\mathrm{CC} 1$ & $\begin{array}{c}\beta \text {-Lactams, CIP, GEN, } \\
\text { RIF }\end{array}$ & $\begin{array}{c}\text { mecA, aacA-aphD, } \\
\text { ant }\left(6^{\prime}\right)-l a\end{array}$ & seg & $\begin{array}{l}\text { sak, sea, } \\
\text { scn, hlb }\end{array}$ & $f n b A, \operatorname{clf} A, \operatorname{clf} B, i c a A$ \\
\hline $\mathrm{NN}$ & Human & Wound swab & $\mathrm{t} 223$ & nt & IV & 18 & ST22 & $\mathrm{CC} 22$ & $\beta$-Lactams & mесA & $\begin{array}{l}\text { seg, sei, tsst-1, } \\
\text { PVL }\end{array}$ & $\begin{array}{l}\text { chp, sak, } \\
\text { scn, hlb }\end{array}$ & $f n b A, c l f B$ \\
\hline S164 & Human & Sputum & t037 & $\mathrm{dt} 10 \mathrm{a}$ & NT & 9 & ST152 & CC152 & $\begin{array}{l}\beta \text {-Lactams, CIP, GEN, } \\
\text { TET, CHL, ERY, CLI }\end{array}$ & $\begin{array}{c}m e c A, a a c A-a p h D, \\
\text { ant }\left(6^{\prime}\right)-\operatorname{Ia}, \operatorname{erm}(\mathrm{C}), \text { tet }(\mathrm{K}), \\
\operatorname{tet}(\mathrm{M}), \operatorname{cat} \mathrm{p}_{\mathrm{p} C 221}\end{array}$ & sea & $\begin{array}{l}\text { sak, sea, } \\
\text { scn, hlb }\end{array}$ & $f n b A, \operatorname{clf} A, \operatorname{clfB}, i c a A$ \\
\hline S239 & Human & $\begin{array}{c}\text { Nipple } \\
\text { discharge }\end{array}$ & t037 & $\mathrm{dt} 11 \mathrm{c}$ & III & 5 & ST239 & CC239 & $\begin{array}{c}\beta \text {-Lactams, CIP, GEN, } \\
\text { ERY, CLI }\end{array}$ & $\begin{array}{c}m e c A, \text { aacA-aphD, } \\
\operatorname{ant}\left(6^{\prime}\right)-\operatorname{Ia}, \operatorname{erm}(\mathrm{C}), \operatorname{tet}(\mathrm{M})\end{array}$ & sea & $\begin{array}{l}\text { sak, sea, } \\
\text { scn, hlb }\end{array}$ & $f n b A, c l f A, c l f B, c n a, i c a A$ \\
\hline S241 & Human & Wound swab & t037 & $\mathrm{dt} 11 \mathrm{c}$ & $\begin{array}{c}\text { III + } \\
\text { SCCmercury }\end{array}$ & 6 & ST239 & CC239 & $\begin{array}{l}\beta \text {-Lactams, CIP, GEN, } \\
\text { TET, ERY, CHL, CLI }\end{array}$ & $\begin{array}{c}m e c A, \operatorname{aacA}-\operatorname{aph} D, \\
\operatorname{ant}\left(6^{\prime}\right)-\operatorname{Ia}, \operatorname{erm}(\mathrm{C}), \operatorname{tet}(\mathrm{K}), \\
\operatorname{tet}(\mathrm{M}), \operatorname{fex} A, \operatorname{cat} \mathrm{pC}_{\mathrm{pC} 21}\end{array}$ & sea & $\begin{array}{l}\text { sak, sea, } \\
\text { scn, hlb }\end{array}$ & $f n b A, \operatorname{clf} A, \operatorname{clf} B, c n a, i c a A$ \\
\hline S245 & Human & Wound swab & t037 & $\mathrm{dt} 11 \mathrm{c}$ & $\begin{array}{c}\text { III + } \\
\text { SCCmercury }\end{array}$ & 7 & ST239 & CC239 & $\begin{array}{l}\beta \text {-Lactams, CIP, GEN, } \\
\text { AMK, TET, CHL }\end{array}$ & $\begin{array}{c}m e c A, \text { aacA-aphD, } \\
\text { ant }\left(6^{\prime}\right)-\operatorname{Ia}, \operatorname{tet}(\mathrm{K}), \operatorname{tet}(\mathrm{M}) \\
\text { fexA }, \operatorname{cat} t_{\mathrm{pC} 221}\end{array}$ & sea & $\begin{array}{l}\text { sak, sea, } \\
\text { scn, hlb }\end{array}$ & $f n b A, c l f A, c l f B, c n a, i c a A$ \\
\hline S246 & Human & Wound swab & t037 & $\mathrm{dt11c}$ & III & 8 & ne & CC239 & $\begin{array}{c}\beta \text {-Lactams, CIP, GEN, } \\
\text { ERI, CLI }\end{array}$ & $\begin{array}{c}m e c A, \operatorname{aacA} A-\operatorname{aph} D, \\
\operatorname{ant}\left(6^{\prime}\right)-\operatorname{Ia}, \operatorname{erm}(\mathrm{C}), \operatorname{tet}(\mathrm{M})\end{array}$ & sea & $\begin{array}{l}\text { sak, sea, } \\
\text { sch, hlb }\end{array}$ & $f n b A, \operatorname{clf} A, \operatorname{clf} B, c n a, i c a A$ \\
\hline S255 & Human & Wound swab & t037 & $\mathrm{dt} 11 \mathrm{c}$ & III & 8 & ne & CC239 & $\begin{array}{c}\beta \text {-Lactams, CIP, GEN, } \\
\text { ERY, CLI }\end{array}$ & $\begin{array}{c}m e c A, \operatorname{aacA} A-\operatorname{aph} D, \\
\operatorname{ant}\left(6^{\prime}\right)-\operatorname{Ia}, \operatorname{erm}(\mathrm{C}), \operatorname{tet}(\mathrm{M})\end{array}$ & sea & $\begin{array}{l}\text { sak, sea, } \\
\text { scn, hlb }\end{array}$ & $f n b A, \operatorname{clf} A, \operatorname{clf} B, c n a, i c a A$ \\
\hline S257 & Human & Sputum & t037 & $\mathrm{dt} 11 \mathrm{c}$ & III & 8 & ST239 & СC239 & $\begin{array}{c}\beta \text {-Lactams, CIP, GEN, } \\
\text { ERY, CLI }\end{array}$ & $\begin{array}{l}m e c A, \text { aacA-aphD, } \\
\operatorname{ant}\left(6^{\prime}\right)-\operatorname{Ia}, \operatorname{erm}(\mathrm{C})\end{array}$ & sea & $\begin{array}{l}\text { sak, sea, } \\
\text { sch, hlb }\end{array}$ & $f n b A, c l f A, c l f B, c n a, i c a A$ \\
\hline S399 & Human & Wound swab & t037 & dr11c & NT & 10 & ST239 & СC239 & $\beta$-Lactams, CIP, GEN & $\begin{array}{l}\operatorname{mec} A, \operatorname{aac} A-\operatorname{aph} D, \\
\operatorname{ant}\left(6^{\prime}\right)-\operatorname{Ia}, \operatorname{tet}(\mathrm{M})\end{array}$ & sea, sei & $\begin{array}{l}\text { sak, sep, } \\
\text { sch, hlb }\end{array}$ & $f n b A, \operatorname{clf} A, \operatorname{clf} B, c n a, i c a A$ \\
\hline S401 & Human & Wound swab & t037 & dr11c & NT & 11 & ne & CC239 & $\beta$-Lactams, CIP, GEN & $\begin{array}{l}m e c A, \text { aacA-aphD, } \\
\operatorname{ant}\left(6^{\prime}\right)-\operatorname{Ia}, \operatorname{tet}(\mathrm{M})\end{array}$ & sea & $\begin{array}{l}\text { sak, sep, } \\
\text { sch, hlb }\end{array}$ & $f n b A, c l f A, c l f B, c n a, i c a A$ \\
\hline 5473 & Human & Wound swab & t037 & $\mathrm{dt11c}$ & III & 11 & ne & CC239 & $\beta$-Lactams, CIP, GEN & $\begin{array}{l}m e c A, \text { aacA-aphD, } \\
\operatorname{ant}\left(6^{\prime}\right)-\operatorname{Ia}, \operatorname{tet}(\mathrm{M})\end{array}$ & sea & $\begin{array}{l}\text { sak, sea, } \\
\text { scn, hlb }\end{array}$ & $f n b A, c l f B, c n a$ \\
\hline S474 & Human & Wound swab & t038 & $\mathrm{dt} 11 \mathrm{c}$ & III & 11 & ne & СC239 & $\begin{array}{c}\beta \text {-Lactams, CIP, GEN, } \\
\text { ERY, CLI }\end{array}$ & $\begin{array}{c}m e c A, \text { accA-aphD, } \\
\operatorname{ant}\left(6^{\prime}\right)-\operatorname{Ia}, \operatorname{erm}(\mathrm{C}), \operatorname{tet}(\mathrm{M})\end{array}$ & sea, sei & $\begin{array}{l}\text { sak, sea, } \\
\text { scn, hlb }\end{array}$ & $f n b A, c l f B, c n a$ \\
\hline S475 & Human & Wound swab & t039 & $\mathrm{dt11c}$ & III & 12 & ST239 & CC239 & $\begin{array}{c}\beta \text {-Lactams, CIP, GEN, } \\
\text { ERY, CLI }\end{array}$ & $\begin{array}{c}m e c A, \operatorname{aacA-aphD,} \\
\operatorname{ant}\left(6^{\prime}\right)-\operatorname{Ia} \operatorname{erm}(\mathrm{C}), \operatorname{tet}(\mathrm{M})\end{array}$ & - & $\begin{array}{l}\text { sak, sch, } \\
\text { hlb }\end{array}$ & $f n b A, c l f B, c n a$ \\
\hline S476 & Human & Wound swab & to40 & $\mathrm{dt11c}$ & III & 11 & ne & CC239 & $\beta$-Lactams, CIP, GEN & $\begin{array}{l}\text { mecA, aacA-aphD, } \\
\operatorname{ant}\left(6^{\prime}\right)-\operatorname{Ia}, \operatorname{tet}(\mathrm{M})\end{array}$ & sea & $\begin{array}{l}\text { sak, sea, } \\
\text { sch, hlb }\end{array}$ & fnbA, clfB, cna \\
\hline S478 & Human & Wound swab & t041 & $\mathrm{dt11c}$ & III & 11 & ST239 & СC239 & $\begin{array}{c}\beta \text {-Lactams, CIP, GEN, } \\
\text { ERY, CLI }\end{array}$ & $\begin{array}{c}m e c A, \operatorname{aacA}-\operatorname{aph} D, \\
\operatorname{ant}\left(6^{\prime}\right)-\operatorname{Ia}, \operatorname{erm}(\mathrm{C}), \operatorname{tet}(\mathrm{M})\end{array}$ & sea & $\begin{array}{l}\text { sak, sea, } \\
\text { sch, hlb }\end{array}$ & $f n b A, c l f B, c n a$ \\
\hline S386 & Dog & Eye swab & t2029 & $\mathrm{dt11c}$ & III & 17 & ST239 & CC239 & $\begin{array}{l}\beta \text {-Lactams, CIP, TET, } \\
\text { ERY, CLI (inducible) }\end{array}$ & $\begin{array}{c}\text { mecA, ant }\left(6^{\prime}\right)-\operatorname{Ia}, \operatorname{erm}(\mathrm{C}), \\
\operatorname{tet}(\mathrm{K}), \operatorname{tet}(\mathrm{M})\end{array}$ & sea & $\begin{array}{l}\text { sak, sea, } \\
\text { scn, hlb }\end{array}$ & $f n b A, \operatorname{clf} A, \operatorname{clf} B, c n a, i c a A$ \\
\hline 5400 & Human & Wound swab & t4789 & dr11c & NT & 22 & ne & СС239 & $\begin{array}{l}\beta \text {-Lactams, CIP, GEN, } \\
\text { ERY, CLI }\end{array}$ & $\begin{array}{c}m e c A, \operatorname{aacA} A-\operatorname{aph} D, \\
\operatorname{ant}\left(6^{\prime}\right)-\operatorname{Ia}, \operatorname{erm}(\mathrm{C}), \operatorname{tet}(\mathrm{M})\end{array}$ & sea, sei & $\begin{array}{l}\text { sak, sep, } \\
\text { sch, hlb }\end{array}$ & $f n b A, \operatorname{clf} A, c l f B, c n a, i c a A$ \\
\hline S402 & Human & Wound swab & t4789 & dr11c & III & 22 & ST239 & CC239 & $\begin{array}{c}\beta \text {-Lactams, CIP, GEN, } \\
\text { ERY, CLI }\end{array}$ & $\begin{array}{c}m e c A, \operatorname{aacA}-a p h D, \\
\operatorname{ant}\left(6^{\prime}\right)-\operatorname{Ia}, \operatorname{erm}(\mathrm{C}), \operatorname{tet}(\mathrm{M})\end{array}$ & sea & $\begin{array}{l}\text { sak, sep, } \\
\text { scn }\end{array}$ & $f n b A, c l f A, c l f B, c n a, i c a A$ \\
\hline
\end{tabular}


Table 1. Cont.

\begin{tabular}{|c|c|c|c|c|c|c|c|c|c|c|c|c|c|}
\hline \multirow[b]{2}{*}{ ID } & \multirow[b]{2}{*}{ Host } & \multirow[b]{2}{*}{ Clinical Site } & \multirow[b]{2}{*}{ spa } & \multirow[b]{2}{*}{$d r u$} & \multirow[b]{2}{*}{ SCCmec } & \multirow[b]{2}{*}{ MLVA * } & \multirow[b]{2}{*}{ ST } & \multirow[b]{2}{*}{$\mathrm{CC}$} & \multicolumn{2}{|c|}{ Antimicrobial Resistance } & \multirow{2}{*}{$\begin{array}{l}\text { Virulence } \\
\text { Factors }\end{array}$} & \multirow[b]{2}{*}{ IEC $* * *$} & \multirow[b]{2}{*}{ Miscellaneous Genes **** } \\
\hline & & & & & & & & & Phenotype ** & Genes Detected & & & \\
\hline S403 & Human & Wound swab & t4789 & dr11c & III & 23 & ST239 & CC239 & $\beta$-Lactams, CIP, GEN & $\begin{array}{l}\operatorname{mec} A, \text { aacA-aphD, } \\
\text { ant }\left(6^{\prime}\right)-\operatorname{Ia}, \text { tet }(\mathrm{M})\end{array}$ & sea & $\begin{array}{l}\text { sak, sep, } \\
\text { scn, hlb }\end{array}$ & $f n b A, c l f A, c l f B, c n a, i c a A$ \\
\hline $\mathrm{S} 480$ & Human & Wound swab & t4789 & $\mathrm{dt} 11 \mathrm{c}$ & NT & 22 & ne & CC239 & $\begin{array}{l}\beta \text {-Lactams, CIP, GEN, } \\
\text { ERY, CLI }\end{array}$ & $\begin{array}{c}m e c A, \operatorname{aacA}-\operatorname{aph} D, \\
\operatorname{ant}\left(6^{\prime}\right)-\operatorname{Ia}, \operatorname{erm}(\mathrm{C}), \operatorname{tet}(\mathrm{M})\end{array}$ & sea & $\begin{array}{l}\text { sak, scn, } \\
\text { hlb }\end{array}$ & $c l f B, c n a$ \\
\hline S479 & Human & Wound swab & $\mathrm{t} 487$ & $\mathrm{dt} 11 \mathrm{c}$ & III & 25 & ST239 & CC239 & $\begin{array}{l}\beta \text {-Lactams, CIP, GEN, } \\
\text { ERY, CLI }\end{array}$ & $\begin{array}{c}m e c A, \operatorname{aacA-aphD}, \\
\operatorname{ant}\left(6^{\prime}\right)-\operatorname{Ia}, \operatorname{erm}(\mathrm{C}), \operatorname{tet}(\mathrm{M})\end{array}$ & sea & $\begin{array}{l}\text { sak, sea, } \\
\text { scn, hlb }\end{array}$ & $f n b A, c l f B, c n a$ \\
\hline S244a & Human & Wound swab & t685 & dt10a & NT & 26 & ST938 & СС30 & $\beta$-Lactams, ERY, CLI & $\begin{array}{c}m e c A, \operatorname{ant}\left(6^{\prime}\right)-\operatorname{Ia}, \operatorname{erm}(\mathrm{A}), \\
\operatorname{erm}(\mathrm{B})\end{array}$ & seg, sei, tsst- 1 & $\begin{array}{l}\text { sak, scn, } \\
\text { hlb }\end{array}$ & $f n b A, c l f A, c l f B, i c a A$ \\
\hline S244b & Human & Wound swab & t685 & dt10a & IV & 27 & ST938 & СС30 & $\beta$-Lactams, ERY, CLI & $m e c A, \operatorname{erm}(\mathrm{A}), \operatorname{erm}(\mathrm{B})$ & seg, sei, tsst-1 & $\begin{array}{l}\text { sak, scn, } \\
\text { hlb }\end{array}$ & $f n b A, \operatorname{clf} A, \operatorname{clfB} B, i c a A$ \\
\hline S398 & Dog & Skin swab & $\mathrm{t} 487$ & dt10g & NT & 24 & ST45 & $\mathrm{CC} 45$ & $\beta$-Lactams & $m e c A$, ant $\left(6^{\prime}\right)-I a$ & seg, sei & $\begin{array}{l}\text { chp, sak, } \\
\text { scn }\end{array}$ & $f n b A, \operatorname{clfA}, \operatorname{clfB} B, i c a A$ \\
\hline S395 & Human & Wound swab & nt & nt & NT & 1 & ST111 & CC5 & $\begin{array}{l}\beta \text {-Lactams, CIP, GEN, } \\
\text { ERY, CLI, RIF }\end{array}$ & $\begin{array}{c}m e c A, \operatorname{aacA-aphD}, \\
\operatorname{ant}\left(6^{\prime}\right)-\operatorname{la}, \operatorname{erm}(\mathrm{A}), \operatorname{erm}(\mathrm{B})\end{array}$ & sea & $\begin{array}{l}\text { sak, scn, } \\
\text { hlb }\end{array}$ & $f n b A, c l f B, i c a A$ \\
\hline S258 & Human & Wound swab & t041 & $\mathrm{dt} 8 \mathrm{~h}$ & I & 13 & ST111 & CC5 & $\begin{array}{l}\beta \text {-Lactams, CIP, GEN, } \\
\text { ERY, CLI }\end{array}$ & $\begin{array}{l}m e c A, \operatorname{aac} A-a p h D, \\
\operatorname{ant}\left(6^{\prime}\right)-\operatorname{Ia}, \operatorname{erm}(\mathrm{A}) \\
\operatorname{erm}(\mathrm{B}), \operatorname{tet}(\mathrm{M})\end{array}$ & sea, seg, sei & $\begin{array}{l}\text { sak, sea, } \\
\text { sch, hlb }\end{array}$ & $f n b A, c l f B, i c a A$ \\
\hline S396 & Human & Nose swab & t12886 & dt10a & IV & 16 & ST5 & CC5 & $\begin{array}{l}\beta \text {-Lactams, ERY, CLI } \\
\text { (inducible) }\end{array}$ & $\operatorname{erm}(\mathrm{A}), \operatorname{erm}(\mathrm{B})$ & $\begin{array}{l}\text { sea, sed, seg, } \\
\text { sei }\end{array}$ & $\begin{array}{l}\text { chp, sak, } \\
\text { scn, hlb }\end{array}$ & $f n b A, c l f A, c l f B, i c a A$ \\
\hline MRS1 & Dog & Wound swab & $\mathrm{t} 242$ & dt10a & NT & 19 & & CC5 & $\beta$-Lactams, GEN & aacA-aphD & seg, sei & $\begin{array}{l}\text { chp, sak, } \\
\text { sea, scn, } \\
\text { hlb }\end{array}$ & $f n b A, c l f A, c l f B, i c a A$ \\
\hline MRS2 & Dog & Wound swab & $\mathrm{t} 242$ & dt10a & NT & 19 & ST5 & CC5 & $\beta$-Lactams, GEN & aacA-aphD & seg, sei & $\begin{array}{l}\text { chp, sak, } \\
\text { scn, hlb }\end{array}$ & $f n b A, c l f A, c l f B, i c a A$ \\
\hline MRS3 & Dog & Ear swab & $\mathrm{t} 242$ & dt10a & $\mathrm{v}$ & 20 & ST5 & CC5 & $\beta$-Lactams & aacA-aphD & seg, sei & $\begin{array}{l}\text { chp, sak, } \\
\text { scn, hlb }\end{array}$ & $f n b A, c l f B$ \\
\hline $\mathrm{S} 422$ & Human & Ear swab & t024 & $\mathrm{dt} 7 \mathrm{f}$ & IV & 2 & ST8 & CC8 & $\begin{array}{l}\text { } \text {-Lactams, GEN, ERY, } \\
\text { CLI (inducible) }\end{array}$ & $\begin{array}{c}\operatorname{aacA-aphD,}, \operatorname{ant}\left(\sigma^{\prime}\right)-\operatorname{Ia}, \\
\operatorname{erm}(\mathrm{C})\end{array}$ & sej & $\begin{array}{l}\text { sak, scn, } \\
\text { hlb }\end{array}$ & $f n b A, \operatorname{clf} A, \operatorname{clf} B$ \\
\hline S423 & Human & Nose swab & t044 & $\mathrm{dt} 10$ & IV & 14 & ST80 & CC 80 & $\beta$-Lactams, TET & $\begin{array}{c}\text { aacA-aphD, ant }\left(6^{\prime}\right)-I a, \\
\operatorname{tet}(\mathrm{K})\end{array}$ & PVL & $\begin{array}{l}\text { sak, scn, } \\
\text { hlb }\end{array}$ & $f n b A, \operatorname{clf} A, \operatorname{clf} B, i c a A$ \\
\hline S256 & Human & Wound swab & t030 & $\mathrm{d}+8 \mathrm{a}$ & $\begin{array}{c}\text { III + } \\
\text { SCCmercury }\end{array}$ & 3 & ST444 & - & $\begin{array}{l}\text { } \text {-Lactams, CIP, GEN, } \\
\text { TET, ERY, CLI, RIF }\end{array}$ & $\begin{array}{c}\operatorname{aacA-aphD}, \operatorname{ant}\left(6^{\prime}\right)-I a, \\
\operatorname{erm}(\mathrm{A}), \operatorname{erm}(\mathrm{B}), \operatorname{erm}(\mathrm{C}), \\
\operatorname{tet}(\mathrm{M})\end{array}$ & sea & $\begin{array}{l}\text { sak, sea, } \\
\text { scn, hlb }\end{array}$ & $\begin{array}{c}\text { fnbA, clf } A, \operatorname{clfB} B, c n a, i c a A, \\
q a c A B\end{array}$ \\
\hline S195 & Human & Skin swab & t030 & $\mathrm{d}+8 \mathrm{a}$ & III & 4 & ST444 & - & $\begin{array}{c}\text {-L-Lactams, CIP, GEN, } \\
\text { TET, CHL, ERY, CLI, } \\
\text { SXT } \\
\end{array}$ & $\begin{array}{c}\operatorname{aacA-aphD,} \operatorname{erm}(\mathrm{A}), \\
\operatorname{erm}(\mathrm{B}), \operatorname{erm}(\mathrm{C}), \operatorname{tet}(\mathrm{M}), \\
\operatorname{cat} \mathrm{t}_{\mathrm{p} 2221}\end{array}$ & sea & $\begin{array}{l}\text { sak, sea, } \\
\text { sch, hlb }\end{array}$ & $f n b A, c l f A, c l f B, c n a, i c a A$ \\
\hline S394 & Human & Wound swab & t4272 & $\mathrm{dt10q}$ & NT & 21 & ST5907 & - & $\begin{array}{c}\beta \text {-Lactams, GEN, ERY, } \\
\text { CLI }\end{array}$ & $a a c A-a p h D, \operatorname{erm}(\mathrm{C})$ & - & $\begin{array}{l}\text { sak, sea, } \\
\text { scn, hlb }\end{array}$ & $f n b A, \operatorname{clf} A, \operatorname{clfB} B, i c a A, \operatorname{ars} A$ \\
\hline
\end{tabular}

* Multiple locus variable number of tandem repeat analyses (MLVA) cluster. ${ }^{*} \mathrm{CIP}=$ ciprofloxacin; $\mathrm{GEN}=$ gentamicin; TET = tetracycline; $\mathrm{CHL}=$ chloramphenicol; ERY $=$ erythromycin;

$\mathrm{CLI}=$ clindamycin; RIF = rifampin; SXT = trimethoprim-sulfamethoxazole, $\mathrm{ST}=$ sequence type. ${ }^{* * *}$ Immune evasion complex (IEC) genes. ${ }^{* * * *}$ Microbial surface components recognizing

adhesive matrix molecule (MSCRAMM) genes; biofilm formation gene; metal resistance genes; quaternary ammonium compound (QAC) resistance genes. 
One human and two animal MRSA isolates were only resistant to tested $\beta$-lactam antibiotics. Multidrug resistance [19] was observed in 28 isolates originating from humans and in two isolates from animals.

The presence of following antibiotic resistance genes was not detected in any of the tested MRSA

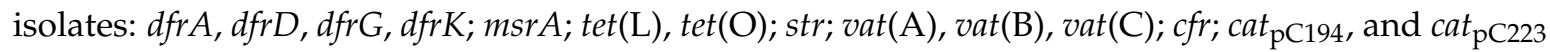
(Table 1).

\subsection{Molecular Characterization}

SCCmec typing of MRSA isolates of human origin revealed the presence of SCCmec type III as the most frequent $(n=16)$, including three isolates with SCCmec type III + SCCmercury, SCCmec type IV $(n=5)$, and I $(n=1)$. Eight MRSA isolates of human origin harbored nontypeable SCCmec. Two MRSA isolates of animal origin carried SCCmec type III and V, while in four MRSA isolates, nontypeable SCCmec elements were found (Table 1).

Among MRSA isolates originating from humans, it was determined that the predominant spa type was $\mathrm{t} 037(n=10)$, followed by $\mathrm{t} 4789(n=4), \mathrm{t} 030(n=2), \mathrm{t} 041(n=2), \mathrm{t} 685(n=2)$, and single tones $\mathrm{t} 024, \mathrm{t} 038, \mathrm{t} 039, \mathrm{t} 040, \mathrm{t} 044, \mathrm{t} 223, \mathrm{t} 487, \mathrm{t} 1288$, and $\mathrm{t} 4272$. For one isolate, the protein $\mathrm{A}$ variable region could not be amplified by PCR. The predominant spa type among MRSA isolates originating from companion animals was $\mathrm{t} 242(n=3)$, followed by single tones $\mathrm{t} 127, \mathrm{t} 487$, and $\mathrm{t} 2029$ (Table 1 ).

The majority of human MRSA isolates derived at the same time from the hospital revealed a uniform $d r u$ type- $d t 11 c(n=18)$. In addition to this predominant $d r u$ type among human isolates, the presence of several $d r u$ types was detected: $\operatorname{dt} 10 \mathrm{a}(n=4), \mathrm{dt} 8 \mathrm{a}(n=2)$, and single tones $\mathrm{dt} 8 \mathrm{~h}, \mathrm{dt} 10 \mathrm{q}$, $\mathrm{dt7f}$, and dt10, while the $d r u$ type could not be determined for two isolates. The $d r u$ typing of animal MRSA isolates identified four $d r u$ types: $\mathrm{dt10a}(n=3)$ and single tones dt7o, dt10g, and dt11c (Table 1).

The MRSA strains exhibited 27 different multiple locus variable number of tandem repeat analyses (MLVA) types (Table 1).

Among selected MRSAs, twelve sequence types (STs) could be detected (ST1, ST111, ST152, ST22, ST239, ST444, ST45, ST5, ST8, ST80, ST938, and the new one ST5907 with new pta allele number 626, with ST239 being predominant $(n=11)$ (Table 1$)$.

The presence of three MRSA isolates with the same characteristics of the III-t037-dt11c-MLVA cluster 8-ST239 were detected in human specimens, while two MRSA isolates with the NT-t242-dt10a-MLVA cluster 19-ST5 were revealed from dog specimens (Table 1).

The following staphylococcal enterotoxin (SE) genes were detected in MRSA isolates of human origin, sea in 23, seg in five, sei in eight, and sej in one isolate.

MRSA isolates of animal origin harbored sea $(n=1)$, seg $(n=4)$, seh $(n=1)$, and sei $(n=4)$.

Staphylococcal enterotoxin (SE) genes $s e b, s e c$, and see, and exfoliative toxin (ET) genes $e t a$ and $e t b$ were not detected in any of the human and animal isolates.

PVL genes were found in two and the tsst-1 gene was found in three MRSA isolates originating from humans. None of the animal isolates harbored PVL and tsst-1 genes (Table 1).

All examined immune evasion complex (IEC) genes were detected in MRSA isolates of human origin: chp in two, sak in all 30, sea in 16, sep in five, scn in all 30, and hlb in 29 isoaltes. The following IEC genes were identified in MRSA isolates of animal origin, sea in three, chp in four, hlb in five, and sak and scn in all six isolates (Table 1). All tested adhesine genes were found in both human and animal MRSA isolates, respectively: $f n b A$ in 29 and in all six, clfA in 20 and in five, clfB in all 36, and cna in 20 and in one isolate. Gene that mediates biofilm formation $i c a A$ was detected in 21 human isolates and in five animal isolates.

Metal resistance genes $c a d D, \operatorname{cop} B$, and $c z r C$, and QACs resistance gene smr were not detected in the examined human and animal MRSA isolates. One human MRSA isolate carried the ars $A$ gene and one the qac $A B$ gene. 


\section{Discussion}

S. aureus is frequently isolated from specimens of human origin, considering the fact that $30 \%$ of the human population is colonized by S. aureus [20]. The MRSA finding in companion animals raises questions about its origin. Cats and dogs are in close contact with humans, as companion animals are often kept inside the house rather than outside [21]. This brings benefits for both sides but also risks due to transmission of pathogens [1,22,23]. On the other hand, although MRSA strains causing serious infections in dogs and cats are rarely isolated, they represent a clinical and therapeutic challenge [23]. However, zooantrophogenic transmission of MRSA has also been documented [24,25].

Results of susceptibility testing were in concordance with previously published results from Serbia with an exception of resistance to trimethoprim-sulfamethoxazole, which has not been observed in the past [13]. Generally, MRSA infections are caused by strains belonging to a several clonal complexes where CC5, CC22, and CC45 are prevalent lineages in hospitals, while CC1 and CC80 are often isolated in the community. CC8 and CC30 are pandemic and found in both hospitals and the community [26].

The prevalent spa type in human MRSA isolates was t037, which was previously reported in Australia, Africa as the most prevalent and Asia as the second most prevalent type. In Europe, this has been most the prevalent type in SCCmec III harboring strains [27]. In this study, this type was found in ten MRSA isolates, of which seven contained SCCmec III (including two isolates with SCC mercury) and three had nontypeable SCCmec elements. This t037-(SCCmec) III has different names, including the Brazilian, Hungarian, and Vienna clone [28]. Among ST239 spa types, the most common was t037, suggesting that this spa type represents the ancestral ST239 spa type [29]. ST239-MRSA-III is considered to be the oldest pandemic MRSA strain, and has been circulating in Eastern Europe, but nowadays, in most European countries, it has been replaced by other STs [8,30]. ST239 was observed in the recent study from Serbia, and it was concluded that 34 HA-MRSA isolates collected in the period of three years belonged to the single 'Serbian clade' closely related to the Turkish clade [13]. One t037-SCCmec nontypable PVL-positive MRSA isolate belonged to ST152. This ST was previously described in patients tied with Macedonia and Kosovo [8] and in Serbia with a similar resistance pattern, different spa types, and SCCmec type V [16]. It has been hypothesized that the PVL-positive ST152 MRSA cluster in Central Europe originated from sub-Saharan Africa [31]. Further, isolate ST80-t044-IV possessed PVL genes. The presence of ST80-t044-IV, PVL-positive strains was previously described in a healthcare worker from Belgrade hospital and from an outpatient in Kragujevac, Serbia [14,16]. Additionally, this spa type was previously found in CA-MRSA isolates belonging to CC80 (t044, SCCmec IV, and dt10a) from Denmark, which were linked to Serbia [32]. The presence of two MRSA isolates t041 ST111-I and ST239-III was detected in this study, while the presence of this spa type and CC5-MRSA-I was observed in isolates from Serbia as well as Croatia [14,33]. In human MRSA isolates, two ST444-t030-III were found. The spa type $\mathrm{t} 030$ was previously reported in Serbia in hospitalized patients and healthcare workers [14,34].

One of our MRSA isolates was ST8-t024-IV. ST8-IV belongs to CA-MRSA, and it has been commonly found in Europe [35].

During the present study, one isolate was spa type t039 and belonged to ST239-III. MRSA carrying the same SCCmec element and belonged to the same spa type was isolated from a patient with osteomyelitis in Germany, but in that study, isolates were not analyzed by multilocus sequence typing (MLST) [36]. The two human isolates were ST938-t685, one harbored SCCmec IV, and another nontypeable SCCmec, and both were tsst-1 positive. ST938 belongs to the CC30 clade, and t685 was recorded in Germany and the Netherlands and associated with CC30 [37,38] In MRSA isolate ST22-t223-IV, the tsst-1 gene was found. This strain was susceptible to all antibiotics except beta-lactams, which has already been observed in MRSA belonged to the same spa and SCCmec type from Sicily, the Gaza Strip, Jordan, and Kuwait and belonged to ST22 [39,40].

In animal MRSA isolates, ST5-t242 was predominant. In two isolates, SCCmec was nontypeable, and in one, the SCCmec was type V. MRSA isolates belonging to spa type $\mathrm{t} 242$ and harboring SCCmec V were previously described in healthcare workers in Serbia (CC5-MRSA-V-t242) [14]. A multiresistant 
MRSA ST1 isolate originating from a cat with nontypeable SCCmec element belonged to t127, which was previously detected in SCCmec IV-harboring strains from Europe and in strains carrying SCCmec I and IV from America [27]. This spa type has been associated with ST1-MRSA-SCCmec Iva, which is one of the most common CA-MRSA strains in the UK, but it also was found in pigs, except that SCCmec was type V [41]. The spa type t2029 was detected in ST239-MRSA-III and was multidrug-resistant. This spa type was previously described in MRSA isolated from a patient in Cuba [42].

Direct repeat unit $(d r u)$ typing has never been applied in epidemiological analysis of MRSA isolates from Serbia. The dominant $d r u$ type among human MRSA isolates was dt11c. This type was found in 14 isolates carrying SCCmec III (t037, t038, t039, t040, t041, t487, and t4789) and in four isolates carrying nontypeable SCCmec elements (t037, t4789). Further, this dru type was found in an animal MRSA isolate belonging to $\mathbf{t} 2029$ harboring SCCmec III. This dru type was previously reported in MRSA belonging to CC398-V-t011 isolated from a slaughterhouse worker in Germany [43] but also as the most prevalent $d r u$ type in methicillin-resistant and multidrug-resistant strains of Staphylococcus capitis isolated from neonates in an intensive-care unit in France, Belgium, the United Kingdom, and Australia [44]. The second most prevalent $d r u$ type in human isolates was dt10a, which was the most prevalent $d r u$ type in animal isolates. In our study, this $d r u$ type was found in human MRSA isolates harboring SCCmec type IV (ST938-t685, ST5-t12886) and nontypeable SCCmec (ST152-t037, ST938-t685), and in animal MRSA isolates that carried SCCmec type V and nontypeable SCCmec (ST5-t242). The dru type dt10a is a widespread type that has previously been associated with diverse MRSA strains harboring different SCCmec elements and belonging to various clones [45]. The European CA-MRSA ST80-MRSA-IV strain appears to be conserved with respect to dt10a, and this type is the major dru type in Scottish EMRSA-15 and Denmark CC80-MRSA-IV strains [32,46]. Moreover, this $d r u$ type was found in both human and chicken isolates belonging to ST9 (SCCmec IV and t1430) [43]. Both dru types dt10a (SCCmec type IV) and dt11c (SCCmec type III) were found in MRSA strains belonging to ST239-t037 isolated from hospitalized patients in Malaysia [47]. The dru type dt8a was identified in two human MRSA isolates ST444-t030-III. This dru type, together with dt10a was previously detected among ST239-MRSA-III and ST22-MRSA-IV isolates [48]. In one human MRSA isolate, dru type $\mathrm{dt} 8 \mathrm{~h}$ was detected. This isolate belonging to ST111-t041 was the only one harboring SCCmec type I. The $d r u$ type $d t 8 h$ was found in an MRSA strain isolated from a cat in Australia, and it belonged to ST22-MRSA-IV, t379 [49]. One of the human MRSA isolates-ST5907-t4272 - exhibited dru type dt10q with nontypeable SCCmec element. This dru type was previously reported in ST398-MRSA-IV, t011 of bovine origin and chickens [43,50]. One of the human MRSA isolates-ST8-t024-IV-belonged to $d r u$ type dt7f. This $d r u$ type was previously described in ST239-MRSA-III, t030 isolated from a patient in Romania [51].

One animal MRSA isolate-ST45-t487-carried nontypeable SCCmec and exhibited dru type $\mathrm{dt10g}$. This $d r u$ type was previously reported in different Scottish hospitals as well as in Romanian hospitals [46,52]. In one of the animal MRSA isolates, with ST1-t127 belonging to dru type $\mathrm{dt7}$, the SCCmec element was nontypeable. This dru type was previously described in CC1 and CC80-MRSA-IV-t127 isolated from patients in a Romanian hospital [51].

It was reported that every CC lineage had a typical collection of enterotoxin genes, for example, sed-sej-ser located on pathogenicity islands in CC45, while sed-sej-ser found on plasmid were usually detected in CC8. Further, prophage-borne sea was sporadically identified in CC8, CC30, CC45, and CC395. Common HA-MRSA and CA-MRSA lineages carry enterotoxin genes specific to a particular lineage [53]. According to previous reports, SEA has been the most prevalent of all SEs [54], which is in accordance with results of this study. In addition to sea, sei, and seg were detected as the second and third most prevalent SEs genes in humans, respectively, and the most prevalent in isolates from dogs. It has been suggested that human S. aureus isolates harbor the operon egc containing seg and sei [55], but both genes were found in S. aureus isolated from dogs in Portugal [56].

The IEC genes encode proteins which have specific interaction with human immune response: chp (chemotaxis inhibitory protein), sak (staphylokinase), particular enterotoxin genes as sea, sep 
and sek, scn (staphylococcal complement inhibitor), and hlb (haemolysin- $\beta$ ). These genes (human adaptation-related genes) are used as a marker of human origin [57]. The sak and scn genes were found in all 36 isolates, suggesting that all isolates could have human origin.

\section{Materials and Methods}

\subsection{Isolates}

In total, 36 nonrepetitive MRSA isolates from humans $(n=30)$ and companion animals $(n=6,5$ canine, and 1 feline) were included in this study. Human isolates were obtained from different clinical specimens (sputum, wound, nose, ear, and skin swabs) of outpatients and inpatients hospitalized at the Military Medical Academy in Belgrade, Serbia during six months in 2016. In the same period, animal isolates were collected from swabs (wound, skin, eye, and ear) during routine diagnostics at the Department of Microbiology of the Faculty of Veterinary Medicine at the University of Belgrade. The study was conducted in accordance with the Declaration of Helsinki, and the research was approved by the Ethics Committee of the Military Medical Academy in Belgrade, Serbia. Examination of the animal samples was carried out as part of the routine bacteriological diagnostic activities at the Department of Microbiology at the Faculty of Veterinary Medicine, University of Belgrade. Therefore, according to the Good Scientific Practice of the Faculty of Veterinary Medicine at the University of Belgrade, these clinical examinations were not subject to the Faculty of Veterinary Medicine Ethics and Animal Welfare Commission reporting obligations.

\subsection{Identification of Methicillin-Resistant Staphylococcus aureus}

Samples were inoculated on Columbia agar with 5\% sheep blood (bioMérieux, Marcy-1' Etoile, France). Colonies resembling Staphylococcus aureus were subjected to further investigation. Isolates were identified according to standard bacteriological protocols and confirmed using matrix-assisted laser desorption/ionization-time of flight spectrometry (MALDI-TOF, Bruker, Germany). Cefoxitin resistance was confirmed by agar disk diffusion as well as by PCRs for mecA and mecC [58,59].

\subsection{Antibiotic Susceptibility Testing}

Antibiotic susceptibility testing of $S$. aureus isolates was performed using agar disk diffusion on Mueller Hinton II Agar (Becton Dickinson, USA) according to Clinical and Laboratory Standards Institute (CLSI) standard [58]. The following antibiotics were tested; penicillin (10 U), cefoxitin $(30 \mu \mathrm{g})$, erythromycin $(15 \mu \mathrm{g})$, clindamycin $(2 \mu \mathrm{g})$, chloramphenicol $(30 \mu \mathrm{g})$, gentamicin $(10 \mu \mathrm{g})$, amikacin $(30 \mu \mathrm{g})$, trimethoprim-sulfamethoxazole $(1.25 / 23.75 \mu \mathrm{g})$, tetracycline $(30 \mu \mathrm{g})$, ciprofloxacin $(5 \mu \mathrm{g})$, teicoplanin $(30 \mu \mathrm{g})$, rifampin $(5 \mu \mathrm{g})$, and linezolid $(30 \mu \mathrm{g})$ (Becton Dickinson, USA). PCR was conducted for revealing the presence of the following antibiotic resistance genes: $\operatorname{erm}(\mathrm{A})$, $\operatorname{erm}(\mathrm{B})$, and erm $(\mathrm{C})$ (confer resistance to macrolides, lincosamides, and streptogramin $\mathrm{B}$ ); $m s r A$ (confers resistance to macrolides and streptogramin B); vat(A), vat(B), and vat(C) (confer resistance to streptogramin A); cfr (confers resistance to all phenicols, lincosamides, oxazolidinones, pleuromutilins, and streptogramin A); fexA (confers resistance to all phenicols); cat $t_{\mathrm{pC} 194}, c_{\mathrm{pC} 221}$, and cat $_{\mathrm{pC} 223}$ (confer resistance to nonfluorinated phenicols-chloramphenicol); aac-aphD (confers resistance to aminoglycosides-gentamicin, kanamycin, tobramycin, and, when overexpressed, to amikacin); ant $\left(6^{\prime}\right)$-I $a$ and $\operatorname{str}$ (confer resistance to aminoglycoside-streptomycin); $d f r A, d f r D, d f r G$, and $d f r K$ (confer resistance to trimethoprim); tet $(\mathrm{K})$ and tet $(\mathrm{L})$ (confers resistance to tetracyclines except minocycline and glycylcyclines); tet(M) (confers resistance to tetracyclines, including minocycline but excluding glycylcyclines); and tet(O) [60-69].

\subsection{Genotyping of MRSA}

All strains were further genotyped by SCCmec, spa typing, and dru typing, by multiple locus variable number of tandem repeat analyses (MLVA) and by multilocus sequence typing (MLST) [69] of 
selected isolates (each representing a distinct MLVA cluster). Allele and sequence type number were assigned and used for goeBURST analysis using PHYLOViZ [70] (Figure 1).

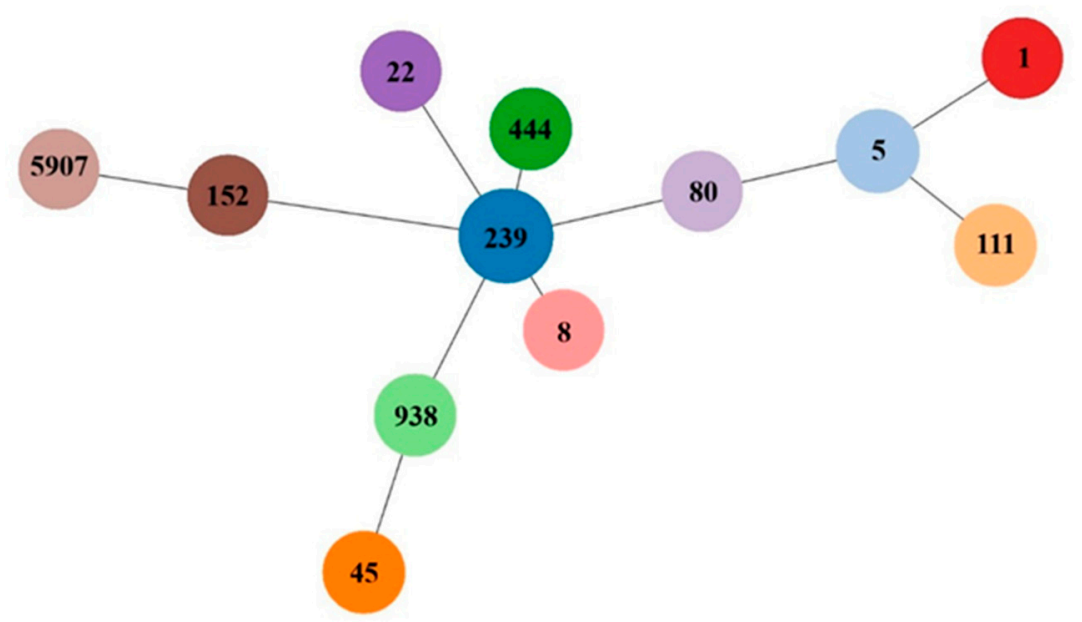

Figure 1. goeBURST diagram for the multilocus sequence typing (MLST) data set (STs in parenthesis) of 27 MRSA isolates. An eBURST diagram was calculated using PHYLOViZ with the goeBURST algorithm. STs were grouped according to their allelic profiles.

\subsection{Detection of Virulence and Other Determinants}

The detection of Panton-Valentine leukocidin (PVL) genes (lukS-PV and $l u k F-P V)$ as well as staphylococcal enterotoxin (SE) genes (sea, seb, sec, sed, see, seg, seh, sei, and sej) and the toxic shock syndrome toxin (TSST) gene (tsst-1) was as previously described [67].

Exfoliative toxin (ET) genes eta and $e t b$ were determined by the PCR protocol previously described [71].

The presence of immune evasion complex (IEC) genes—chemotaxis inhibitory protein gene (chp), staphylokinase gene (sak), staphylococcal enterotoxin A gene (sea), staphylococcal enterotoxin P gene (sep), staphylococcal complement inhibitor gene (scn), and haemolysin- $\beta$ gene ( $h l b)$-was confirmed by the PCR protocol previously described [72].

Microbial surface components recognizing adhesive matrix molecule (MSCRAMMs) genes: fnbA (fibronecting binding protein A), clfA and clfB, (clumping factors A and B), and cna (collagen binding protein) were targeted using the PCR protocol previously described [73].

The presence of the icaA gene that mediates biofilm formation was determined by the PCR protocol previously described [73].

Metal resistance genes $\operatorname{ars} A$ (arsenic compounds), $\operatorname{cadD}$ (cadmium), $\operatorname{copB}$ (copper), and $\operatorname{czrC}$ (zinc/cadmium) genes, as well as genes for quaternary ammonium compound (QACs) resistance ( $q a c A B$ and $s m r$ ) were carried out using PCR as previously described [68].

\section{Conclusions}

This study provided insight into the characteristics of MRSA strains collected from patients in one hospital in Belgrade, as well as from dogs and cat at a certain point of time. Further, this is the first report on MRSA isolates originating from dogs and cat in Serbia. The presence of ST5, ST45, and ST239 MRSA strains was revealed in specimens originating from companion animals. This discovery indicated that MRSA strains moved from hospitals not only to the community and the general population, but also to companion animals. This fact could point out that, to some degree, companion animals might be reservoirs of HA-MRSA strains.

Author Contributions: Conceptualization, J.A., D.M., and I.L.; Methodology, J.A., D.M., K.A., Z.T., B.R., I.K., J.S., and I.L.; Validation, J.A., D.M., J.S., and I.L.; Formal Analysis and Investigation, J.A., D.M., K.A., Z.T., B.R., I.K., and I.L.; Writing—Original Draft Preparation, J.A.; Writing-Review and Editing, J.S. and I.L. 
Funding: This study was partially supported by the Ministry of Education, Science and Technological Development of the Republic of Serbia, Project No. TR31079, http:/ / www.mpn.gov.rs/. The funder had no role in study design, data collection and analysis, decision to publish, or preparation of the manuscript.

Acknowledgments: We are grateful to MDPI's professional English editing service for improving our English style.

Conflicts of Interest: The authors declare no conflict of interest.

\section{References}

1. Morgan, M. Methicillin-resistant Staphylococcus aureus and animals: Zoonosis or humanosis? J. Antimicrob. Chemother. 2008, 62, 1181-1187. [CrossRef] [PubMed]

2. International Working Group on the Classification of Staphylococcal Cassette Chromosome Elements (IWG-SCC). Classification of Staphylococcal Cassette Chromosome mec (SCCmec): Guidelines for Reporting Novel SCCmec Elements. Antimicrob. Agents Chemother. 2009, 53, 4961-4967. [CrossRef] [PubMed]

3. Monecke, S.; Slickers, P.; Gawlik, D.; Müller, E.; Reissig, A.; Ruppelt-Lorz, A.; de Jäckel, S.C.; Feßler, A.T.; Frank, M.; Hotzel, H.; Kadlec, K.; et al. Variability of SCCmec elements in livestock-associated CC398 MRSA. Vet. Microbiol. 2018, 217, 36-46. [CrossRef] [PubMed]

4. Baig, S.; Johannesen, T.B.; Overballe-Petersen, S.; Larsen, J.; Larsen, A.R.; Stegger, M. Novel SCCmec type XIII (9A) identified in an ST152 methicillin-resistant Staphylococcus aureus. Infect. Genet. Evol. 2018, 61, 74-76. [CrossRef]

5. Lakhundi, S.; Zhang, K. Methicillin-Resistant Staphylococcus aureus: Molecular Characterization, Evolution, and Epidemiology. Clin. Microbiol. Rev. 2018, 31, e00020-18. [CrossRef]

6. Köck, R.; Becker, K.; Cookson, B.; van Gemert-Pijnen, J.E.; Harbarth, S.; Kluytmans, J.; Mielke, M.; Peters, G.; Skov, R.L.; Struelens, M.J.; et al. Methicillin-resistant Staphylococcus aureus (MRSA): Burden of disease and control challenges in Europe. Eur. Surveill. 2010, 15, 19688. [CrossRef]

7. Malachowa, N.; DeLeo, F. Mobile genetic elements of Staphylococcus aureus. Cell. Mol. Life Sci. 2010, 67, 3057-3071. [CrossRef] [PubMed]

8. Monecke, S.; Coombs, G.; Shore, A.C.; Coleman, D.C.; Akpaka, P.; Borg, M.; Chow, H.; Ip, M.; Jatzwauk, L.; Jonas, D.; et al. A Field Guide to Pandemic, Epidemic and Sporadic Clones of Methicillin-Resistant Staphylococcus aureus. PLoS ONE 2011, 6, e17936. [CrossRef]

9. McDougal, L.K.; Fosheim, G.E.; Nicholson, A.; Bulens, S.N.; Limbago, B.M.; Shearer, J.E.S.; Summers, A.O.; Patel, J.B. Emergence of Resistance among USA300 Methicillin-Resistant Staphylococcus aureus Isolates Causing Invasive Disease in the United States. Antimicrob. Agents Chemother. 2010, 54, 3804-3811. [CrossRef]

10. Uhlemann, A.C.; Otto, M.; Lowy, F.D.; DeLeo, F.R. Evolution of community- and healthcare-associated methicillin-resistant Staphylococcus aureus. Infect. Genet. Evol. 2013, 21, 563-574. [CrossRef]

11. Morris, D.O.; Loeffler, A.; Davis, M.F.; Guardabassi, L.; Weese, J.S. Recommendations for approaches to meticillin-resistant staphylococcal infections of small animals: Diagnosis, therapeutic considerations and preventative measures. Clinical Consensus Guidelines of the World Association for Veterinary Dermatology. Vet. Dermatol. 2017, 28, 304.e69. [CrossRef]

12. De Backer, S.; Xavier, B.B.; Vanjari, L.; Coppens, J.; Lammens, C.; Vemu, L.; Carevic, B.; Hryniewicz, W.; Jorens, P.; Kumar-Singh, S.; et al. Remarkable geographical variations between India and Europe in carriage of the staphylococcal surface protein-encoding sasX/sesI and in the population structure of methicillin-resistant Staphylococcus aureus belonging to clonal complex 8. Clin. Microbiol. Infect. 2018. [CrossRef]

13. Cirkovic, I.; Stepanovic, S.; Skov, R.; Trajkovic, J.; Grgurevic, A.; Larsen, A.R. Carriage and genetic diversity of methicillin-resistant Staphylococcus aureus among patients and healthcare workers in a Serbian University Hospital. PLoS ONE 2015, 10, e0127347. [CrossRef]

14. Cirkovic, I.; Djukic, S.; Carevic, B.; Mazic, N.; Mioljevic, V.; Stepanovic, S. Methicillin-resistant Staphylococcus aureus nasal carriage among hospitalized patients and healthcare workers in the Clinical Centre of Serbia. Arch. Biol Sci. 2014, 66, 87-92. [CrossRef]

15. Cirkovic, I.; Sørum, M.; Radenkovic, D.; Vlahovic, M.S.; Larsen, A.R. National surveillance reveals findings of Panton-Valentine leukocidin positive meticillin-resistant Staphylococcus aureus in Serbia. J. Med. Microbiol. 2013, 62, 342-344. [CrossRef] 
16. Zutic, M.; Cirkovic, I.; Pavlovic, Lj.; Zutic, J.; Asanin, J.; Radanovic, O.; Pavlovic, N. Occurrence of methicillin-resistant Staphylococcus aureus in milk samples from Serbian cows with subclinical mastitis. Afr. J. Microbiol. Res. 2012, 6, 5887-5889. [CrossRef]

17. Zutic, M.; Cirkovic, I.; Pavlovic, Lj.; Asanin, J.; Jovanovic, S.; Zutic, J.; Asanin, R. First isolation of methicillin-resistant Staphylococcus aureus from pigs'clinical samples in Serbia. Acta Vet. Brno. 2012, 81, 225-227. [CrossRef]

18. Velebit, B.; Fetsch, A.; Mirilovic, M.; Teodorovic, V.; Jovanovic, M. MRSA in pigs in Serbia. Vet. Rec. 2010, 167, 183-184. [CrossRef]

19. Sweeney, M.; Lubbers, B.; Schwarz, S.; Watts, J. Applying definitions for multidrug resistance extensive drug resistance and pandrug resistance to clinically significant livestock and companion animal bacterial pathogens. J. Antimicrob. Chemother. 2018, 73, 1460-1463. [CrossRef]

20. Van Belkum, A.; Melles, D.C.; Nouwen, J.; van Leeuwen, W.B.; van Wamel, W.; Vos, M.C.; Wertheim, H.F.L.; Verbrugh, H.A. Co-evolutionary aspects of human colonisation and infection by Staphylococcus aureus. Infect. Genet. Evol. 2009, 9, 32-47. [CrossRef]

21. Bierowiec, K.; Płoneczka-Janeczko, K.; Rypuła, K. Is the Colonisation of Staphylococcus aureus in Pets Associated with Their Close Contact with Owners? PLoS ONE 2016, 11, e0156052. [CrossRef]

22. Guardabassi, L.; Larsen, J.; Weese, J.S.; Butaye, P.; Battisti, A.; Kluytmans, J.; Lloyd, D.H.; Skov, R.L. Public health impact and antimicrobial selection of meticillin-resistant staphylococci in animals. J. Glob. Antimicrob. Resist. 2013, 1, 55-62. [CrossRef]

23. Guardabassi, L.; Schwarz, S.; Lloyd, D.H. Pet animals as reservoirs of antimicrobial-resistant bacteria: Review. J. Antimicrob. Chemother. 2004, 54, 321-332. [CrossRef]

24. Loncaric, I.; Brunthaler, R.; Spergser, J. Suspected goat-to-human transmission of methicillin-resistant Staphylococcus aureus sequence type 398. J. Clin. Microbiol. 2013, 51, 1625-1626. [CrossRef]

25. Loncaric, I.; Künzel, F.; Klang, A.; Wagner, R.; Licka, T.; Grunert, T.; Feßler, A.T.; Geier-Dömling, D.; Rosengarten, R.; Müller, E.; et al. Carriage of meticillin-resistant staphylococci between humans and animals on a small farm. Vet. Dermatol. 2016, 27, 191-e48. [CrossRef]

26. Baldan, R.; Rancoita, P.M.V.; Di Serio, C.; Mazzotti, M.; Cichero, P.; Ossi, C.; Biancardi, A.; Nizzero, P.; Saracco, A.; Scarpellini, P.; et al. Epidemic MRSA clone ST22-IV is more resistant to multiple host- and environment-related stresses compared with ST228-I. J. Antimicrob. Chemother. 2015, 70, 757-765. [CrossRef]

27. Asadollahi, P.; Farahani, N.N.; Mirzaii, M.; Khoramrooz, S.S.; van Belkum, A.; Asadollahi, K.; Dadashi, M.; Darban-Sarokhalil, D. Distribution of the Most Prevalent Spa Types among Clinical Isolates of Methicillin-Resistant and -Susceptible Staphylococcus aureus around the World: A Review. Front. Microbiol. 2018, 9, 163. [CrossRef]

28. Smyth, D.S.; McDougal, L.K.; Gran, F.W.; Manoharan, A.; Enright, M.C.; Song, J.-H.; de Lencastre, H.; Robinson, D.A. Population Structure of a Hybrid Clonal Group of Methicillin-Resistant Staphylococcus aureus, ST239-MRSA-III. PLoS ONE 2010, 5, e8582. [CrossRef]

29. Harris, S.R.; Feil, E.J.; Holden, M.T.G.; Quail, M.A.; Nickerson, E.K.; Chantratita, N.; Gardete, S.; Tavares, A.; Day, N.; Lindsay, J.A.; et al. Evolution of MRSA during hospital transmission and intercontinental spread. Science 2010, 327, 469-474. [CrossRef]

30. Monecke, S.; Slickers, P.; Gawlik, D.; Müller, E.; Reissig, A.; Ruppelt-Lorz, A.; Akpaka, P.E.; Bandt, D.; Bes, M.; Boswihi, S.S.; et al. Molecular Typing of ST239-MRSA-III from Diverse Geographic Locations and the Evolution of the SCCmec III Element during Its Intercontinental Spread. Front. Microbiol. 2018, 9, 1436. [CrossRef]

31. Stegger, M.; Wirth, T.; Andersen, P.S.; Skov, R.L.; De Grassi, A.; Simões, P.M.; Tristan, A.; Petersen, A.; Aziz, M.; Kiil, K.; et al. Origin and evolution of European community-acquired methicillin-resistant Staphylococcus aureus. MBio 2014, 5, e01044-14. [CrossRef]

32. Larsen, A.R.; Böcher, S.; Stegger, M.; Goering, R.; Pallesen, L.V.; Skov, R. Epidemiology of European Community-Associated Methicillin-Resistant Staphylococcus aureus Clonal Complex 80 Type IV Strains Isolated in Denmark from 1993 to 2004. J. Clin. Microbiol. 2008, 46, 62-68. [CrossRef]

33. Budimir, A.; Deurenberg, R.H.; Bosnjak, Z.; Stobberingh, E.E.; Cetkovic, H.; Kalenic, S. A variant of the Southern German clone of methicillin-resistant Staphylococcus aureus is predominant in Croatia. Clin. Microbiol. Infect. 2010, 16, 1077-1083. [CrossRef] 
34. Petersson, A.C.; Olsson-Liljequist, B.; Miorner, H.; Hæggman, S. Evaluating the usefulness of spa typing, in comparison with pulsed-field gel electrophoresis, for epidemiological typing of methicillin-resistant Staphylococcus aureus in a low-prevalence region in Sweden 2000-2004. Clin. Microbiol. Infect. 2010, 16, 456-462. [CrossRef]

35. Strauß, L.; Stegger, M.; Akpaka, P.E.; Alabi, A.; Breurec, S.; Coombs, G.; Egyir, B.; Larsen, A.R.; Laurent, F.; Monecke, S.; et al. Origin, evolution, and global transmission of community-acquired Staphylococcus aureus ST8. PNAS 2017, 114, E10596-E10604. [CrossRef]

36. Garofalo, A.; Giai, C.; Lattar, S.; Gardella, N.; Mollerach, M.; Kahl, B.C.; Becker, K.; Prince, A.S.; Sordelli, D.O.; Gómez, M.I. The Length of the Staphylococcus aureus Protein A Polymorphic Region Regulates Inflammation: Impact on Acute and Chronic Infection. J. Infect. Dis. 2012, 206, 81-90. [CrossRef]

37. Rijnders, M.I.A.; Deurenberg, R.H.; Boumans, M.L.L.; Hoogkamp-Korstanje, J.A.A.; Beisser, P.S.; Stobberingh, E.E. The Antibiotic Resistance Surveillance Group. Population Structure of Staphylococcus aureus Strains Isolated from Intensive Care Unit Patients in The Netherlands over an 11-Year Period (1996 to 2006). J. Clin. Microbiol. 2009, 47, 4090-4095. [CrossRef]

38. Cuny, C.; Layer, F.; Werner, G.; Harmsen, D.; Daniels-Haardt, I.; Jurke, A.; Mellmann, A.; Witte, W.; Köck, R. State-wide surveillance of antibiotic resistance patterns and spa types of methicillin-resistant Staphylococcus aureus from blood cultures in North Rhine-Westphalia, 2011-2013. Clin. Microbiol. Infect. 2015, 21, 750-757. [CrossRef]

39. Aqel, A.A.; Alzoubi, H.M.; Vickers, A.; Pichon, B.; Kearns, A.M. Molecular epidemiology of nasal isolates of methicillin-resistant Staphylococcus aureus from Jordan. J. Infect. Public Health 2015, 8, 90-97. [CrossRef]

40. Udo, E.E.; Boswihi, S.S.; Al-Sweih, N. High prevalence of toxic shock syndrome toxin-producing epidemic methicillin-resistant Staphylococcus aureus 15 (EMRSA-15) strains in Kuwait hospitals. New Microbes New Infect. 2016, 12, 24-30. [CrossRef]

41. Franco, A.; Hasman, H.; Iurescia, M.; Lorenzetti, R.; Stegger, M.; Pantosti, A.; Feltrin, F.; Ianzano, A.; Porrero, M.C.; Liapi, M.; et al. Molecular characterization of spa type t127, sequence type 1 methicillin-resistant Staphylococcus aureus from pigs. J. Antimicrob. Chemother. 2011, 66, 1231-1235. [CrossRef]

42. Hopman, J.; Peraza, G.T.; Espinosa, F.; Klaassen, C.; Velázquez, D.; Meis, J.; Voss, A. Methicillin-resistant Staphylococcus aureus without borders: USA300 in Cuba. BMC Proc. 2011, 5 (Suppl. 6), 172. [CrossRef]

43. Wendlandt, S.; Kadlec, K.; Feßler, A.T.; Monecke, S.; Ehricht, R.; van de Giessen, A.W.; Hengeveld, P.D.; Huijsdens, X.; Schwarz, S.; van Duijkeren, E. Resistance phenotypes and genotypes of methicillin-resistant Staphylococcus aureus isolates from broiler chickens at slaughter and abattoir workers. J. Antimicrob. Chemother. 2013, 68, 2458-2463. [CrossRef]

44. Butin, M.; Rasigade, J.P.; Martins-Simões, P.; Meugnier, H.; Lemriss, H.; Goering, R.V.; Kearns, A.; Deighton, M.A.; Denis, O.; Ibrahimi, A.; et al. Wide geographical dissemination of the multiresistant Staphylococcus capitis NRCS-A clone in neonatal intensive-care units. Clin. Microbiol. Infect. 2016, 22, 46-52. [CrossRef]

45. Bartels, M.D.; Boye, K.; Oliveira, D.C.; Worning, P.; Goering, R.; Westh, H. Associations between $d r u$ Types and SCCmec Cassettes. PLoS ONE 2013, 8, e61860. [CrossRef]

46. Goering, R.V.; Morrison, D.; Al-Doori, Z.; Edwards, G.F.S.; Gemmell, C.G. Usefulness of mec-associated direct repeat unit $(\mathrm{dru})$ typing in the epidemiological analysis of highly clonal methicillin-resistant Staphylococcus aureus in Scotland. Clin. Microbiol. Infect. 2008, 14, 964-969. [CrossRef]

47. Lim, K.T.; Yeo, C.C.; Suhaili, Z.; Thong, K.L. Comparison of Methicillin-Resistant and Methicillin-Sensitive Staphylococcus aureus Strains Isolated from a Tertiary Hospital in Terengganu, Malaysia. Jpn. J. Infect. Dis. 2012, 65, 502-509. [CrossRef]

48. Shore, A.C.; Rossney, A.S.; Kinnevey, P.M.; Brennan, O.M.; Creamer, E.; Sherlock, O.; Dolan, A.; Cunney, R.; Sullivan, D.J.; Goering, R.V.; et al. Enhanced Discrimination of Highly Clonal ST22-Methicillin-Resistant Staphylococcus aureus IV Isolates Achieved by Combining spa, dru, and Pulsed-Field Gel Electrophoresis Typing Data. J. Clin. Microbiol. 2010, 48, 1839-1852. [CrossRef]

49. Worthing, K.A.; Abraham, S.; Pang, S.; Coombs, G.W.; Saputra, S.; Jordan, D.; Wong, H.S.; Abraham, R.J.; Trott, D.J.; Norris, J.M. Molecular Characterization of Methicillin-Resistant Staphylococcus aureus Isolated from Australian Animals and Veterinarians. Microb. Drug. Resist. 2018, 24, 203-212. [CrossRef] 
50. Feßler, A.; Scott, C.; Kadlec, K.; Ehricht, R.; Monecke, S.; Schwarz, S. Characterization of methicillin-resistant Staphylococcus aureus ST398 from cases of bovine mastitis. J. Antimicrob. Chemother. 2010, 65, 619-625. [CrossRef]

51. Ionescu, R.; Mediavilla, J.R.; Chen, L.; Grigorescu, D.O.; Idomir, M.; Kreiswirth, B.N.; Roberts, R.B. Molecular Characterization and Antibiotic Susceptibility of Staphylococcus aureus from a Multidisciplinary Hospital in Romania. Microb. Drug. Resist. 2010, 16, 263-272. [CrossRef]

52. Chen, L.; Mediavilla, J.R.; Smyth, D.S.; Chavda, K.D.; Ionescu, R.; Roberts, R.B.; Robinson, D.A.; Kreiswirth, B.N. Identification of a Novel Transposon (Tn6072) and a Truncated Staphylococcal Cassette Chromosome mec Element in Methicillin-Resistant Staphylococcus aureus ST239. Antimicrob. Agents Chemother. 2010, 54, 3347-3354. [CrossRef]

53. Strommenger, B.; Layer, F.; Werner, G. Staphylococcus aureus and methicillin-resistant Staphylococcus aureus in workers in the food industry. In Staphylococcus aureus, 1st ed.; Fetsch, A., Ed.; Academic Press: Cambridge, MA, USA, 2018; pp. 163-188.

54. Hennekinne, J.A. Staphylococcus aureus as a leading cause of foodborne outbreaks worldwide. In Staphylococcus aureus, 1st ed.; Fetsch, A., Ed.; Academic Press: Cambridge, MA, USA, 2018; pp. 129-146.

55. Smyth, D.S.; Hartigan, P.J.; Meaney, W.J.; Fitzgerald, J.R.; Deobald, C.F.; Bohach, G.A.; Smyth, C.J. Superantigen genes encoded by the egc cluster and SaPIbov are predominant among Staphylococcus aureus isolates from cows, goats, sheep, rabbits and poultry. J. Med. Microbiol. 2005, 54, 401-411. [CrossRef]

56. Couto, N.; Belas, A.; Kadlec, K.; Schwarz, S.; Pomba, C. Clonal diversity, virulence patterns and antimicrobial and biocide susceptibility among human, animal and environmental MRSA in Portugal. J. Antimicrob. Chemother. 2015, 70, 2483-2487. [CrossRef]

57. Zarazaga, M.; Gómez, P.; Ceballos, S.; Torres, C. Molecular epidemiology of Staphylococcus aureus lineages in the animal-human interface. In Staphylococcus aureus, 1st ed.; Fetsch, A., Ed.; Academic Press: Cambridge, MA, USA, 2018; pp. 189-214.

58. Clinical and Laboratory Standards Institute. Performance Standards for Antimicrobial Susceptibility Testing, 26th ed.; CLSI supplement M100S; CLSI: Wayne, PA, USA, 2016; pp. 74-80.

59. Loncaric, I.; Kübber-Heiss, A.; Posautz, A.; Stalder, G.L.; Hoffmann, D.; Rosengarten, R.; Walzer, C. Characterization of methicillin-resistant Staphylococcus spp. carrying the mecC gene, isolated from wildlife. J. Antimicrob. Chemother. 2013, 68, 2222-2225. [CrossRef]

60. Aarestrup, F.M.; AgersŁ, Y.; Ahrens, P.; JŁrgensen, J.C.; Madsen, M.; Jensen, L.B. Antimicrobial susceptibility and presence of resistance genes in staphylococci from poultry. Vet. Microbiol. 2000, 74, 353-364. [CrossRef]

61. Martineau, F.; Picard, F.J.; Lansac, N.; Ménard, C.; Roy, P.H.; Ouellette, M.; Bergeron, M.G. Correlation between the resistance genotype determined by multiplex PCR assays and the antibiotic susceptibility patterns of Staphylococcus aureus and Staphylococcus Antimicrob. Agents Chemother. 2000, 44, 231-238. [CrossRef]

62. Kehrenberg, C.; Schwarz, S. Distribution of florfenicol resistance genes fexA and cfr among chloramphenicol-resistant Staphylococcus isolates. Antimicrob. Agents Chemother. 2006, 50, 1156-1163. [CrossRef]

63. Schnellmann, C.; Gerber, V.; Rossano, A.; Jaquier, V.; Panchaud, Y.; Doherr, M.G.; Thomann, A.; Straub, R.; Perreten, V. Presence of new mecA and $m p h(\mathrm{C})$ variants conferring antibiotic resistance in Staphylococcus spp. isolated from the skin of horses before and after clinic admission. J. Clin. Microbiol. 2006, 44, 4444-4454. [CrossRef]

64. Hauschild, T.; Vukovic, D.; Dakić, I.; Ježek, P.; Djukić, S.; Dimitrijević, V.; Stepanović, S.; Schwarz, S. Aminoglycoside Resistance in Members of the Staphylococcus sciuri Group. Microb. Drug Resist. 2007, 13, 77-84. [CrossRef]

65. Argudín, M.A.; Tenhagen, B.A.; Fetsch, A.; Sachsenröder, J.; Käsbohrer, A.; Schroeter, A.; Hammerl, J.A.; Hertwig, S.; Helmuth, R.; Bräunig, J.; et al. Virulence and resistance determinants of German Staphylococcus aureus ST398 isolates from nonhuman sources. Appl. Environ. Microbiol. 2011, 77, 3052-3060. [CrossRef]

66. Shittu, A.O.; Okon, K.; Adesida, S.; Oyedara, O.; Witte, W.; Strommenger, B.; Layer, F.; Nübel, U. Antibiotic resistance and molecular epidemiology of Staphylococcus aureus in Nigeria. BMC Microbiol. 2011, 11, 92. [CrossRef] 
67. Loncaric, I.; Künzel, F.; Licka, T.; Simhofer, H.; Spergser, J.; Rosengarten, R. Identification and characterization of methicillin-resistant Staphylococcus aureus (MRSA) from Austrian companion animals and horses. Vet. Microbiol. 2014, 168, 381-387. [CrossRef]

68. Schauer, B.; Krametter-Frötscher, R.; Knauer, F.; Ehricht, R.; Monecke, S.; Feßler, A.T.; Schwarz, S.; Grunert, T.; Spergser, J.; Loncaric, I. Diversity of methicillin-resistant Staphylococcus aureus (MRSA) isolated from Austrian ruminants and New World camelids. Vet. Microbiol. 2018, 215, 77-82. [CrossRef]

69. Feßler, A.T.; Li, J.; Kadlec, K.; Wang, Y.; Schwarz, S. Antimicrobial resistance properties of Staphylococcus aureus. In Staphylococcus aureus, 1st ed.; Fetsch, A., Ed.; Academic Press: Cambridge, MA, USA, 2018; pp. 57-85.

70. Francisco, A.P.; Vaz, C.; Monteiro, P.T.; Melo-Cristino, J.; Ramirez, M.; Carriço, J.A. PHYLOViZ: Phylogenetic inference and data visualization for sequence based typing methods. BMC Bioinform. 2012, 13, 87. [CrossRef]

71. Mehrotra, M.; Wang, G.; Johnson, W.M. Multiplex PCR for detection of genes for Staphylococcus aureus enterotoxins, exfoliative toxins, toxic shock syndrome toxin 1, and methicillin resistance. J. Clin. Microbiol. 2000, 38, 1032-1035.

72. Van Wamel, W.J.; Rooijakkers, S.H.; Ruyken, M.; van Kessel, K.P.; van Strijp, J.A. The innate immune modulators staphylococcal complement inhibitor and chemotaxis inhibitory protein of Staphylococcus aureus are located on beta-hemolysin-converting bacteriophages. J. Bacteriol. 2006, 188, 1310-1315. [CrossRef]

73. Peacock, S.J.; Moore, C.E.; Justice, A.; Kantzanou, M.; Story, L.; Mackie, K.; O’Neill, G.; Day, N.P. Virulent combinations of adhesin and toxin genes in natural populations of Staphylococcus aureus. Infect. Immun. 2002, 70, 4987-4996. [CrossRef]

(C) 2019 by the authors. Licensee MDPI, Basel, Switzerland. This article is an open access article distributed under the terms and conditions of the Creative Commons Attribution (CC BY) license (http:/ / creativecommons.org/licenses/by/4.0/). 